\title{
Advancing urban water security: The urbanization of water-society relations and entry-points for political engagement
}

DOI:

10.1080/02508060.2021.1937901

\section{Document Version}

Accepted author manuscript

Link to publication record in Manchester Research Explorer

\section{Citation for published version (APA):}

Empinotti, V. L., Budds, J., Jepson, W., Millington, N., Ferrara, L. N., Geere, J-A., Grandisoli, E., Paz, M. G. A. D., Puga, B. P., Alves, E. M., Cawood, S., Jacobi, P. R., Kinjo, V. U., Lampis, A., Moretti, R., Octavianti, T., Periotto, N., Quinn, R., Quintsir, S., ... Wahby, N. (2021). Advancing urban water security: The urbanization of water-society relations and entry-points for political engagement. Water International, 46(6), 956-968.

https://doi.org/10.1080/02508060.2021.1937901

\section{Published in:}

Water International

\section{Citing this paper}

Please note that where the full-text provided on Manchester Research Explorer is the Author Accepted Manuscript or Proof version this may differ from the final Published version. If citing, it is advised that you check and use the publisher's definitive version.

\section{General rights}

Copyright and moral rights for the publications made accessible in the Research Explorer are retained by the authors and/or other copyright owners and it is a condition of accessing publications that users recognise and abide by the legal requirements associated with these rights.

\section{Takedown policy}

If you believe that this document breaches copyright please refer to the University of Manchester's Takedown Procedures [http://man.ac.uk/04Y6Bo] or contact uml.scholarlycommunications@manchester.ac.uk providing relevant details, so we can investigate your claim.

\section{OPEN ACCESS}




\section{Water International}

\section{Advancing urban water security: The urbanization of water-society relations and entry- points for political engagement \\ --Manuscript Draft--}

Full Title:

Advancing urban water security: The urbanization of water-society relations and entrypoints for political engagement

\section{Manuscript Number:}

\section{Article Type:}

Keywords:

Abstract:

Order of Authors:

water governance, water security, urbanization, political ecology, uneven development, territory

We seek to advance a critical and relational concept of urban water security that theorizes urban processes in relation to the hydro-social dynamics that produce experiences of water securities and insecurities at multiple scales. Our intention is to set out an analytical framework that both examines the social relations that underpin water insecurity and goes beyond the urban as merely the context in which water provision and risk take place. We seek to mobilize this concept to envision meaningful water policies and hydro-social practices to enhance social equity and empowerment for urban communities.

\section{Viewpoint}

\begin{tabular}{|l|}
\hline Vanessa Empinotti \\
\hline Jessica Budds \\
\hline Wendy Jepson \\
\hline Nate Millington \\
\hline Luciana Nicolau Ferrara \\
\hline Jo-Anee Geere \\
\hline Edson Grandisoli \\
\hline Mariana Gutierres Arteiro da Paz \\
\hline Bruno Peregrina Puga \\
\hline Estela Macedo Alves \\
\hline Sally Cawood \\
\hline Pedro Roberto Jacobi \\
\hline Victor Uehara Kinjo \\
\hline Andrea Lampis \\
\hline Ricardo Moretti \\
\hline Thanti Octavianti \\
\hline Natalia Periotto \\
\hline Ruth Quinn \\
\hline Suyá Quintslr \\
\hline Samia Sullaiman \\
\hline Naula Arce Vicente \\
\hline
\end{tabular}




\title{
Advancing urban water security: The urbanization of water-society relations and entry-points for political engagement
}

\author{
We seek to advance a critical and relational concept of urban water security that \\ theorizes urban processes in relation to the hydro-social dynamics that produce \\ experiences of water securities and insecurities at multiple scales. Our intention is \\ to set out an analytical framework that both examines the social relations that \\ underpin water insecurity and goes beyond the urban as merely the context in \\ which water provision and risk take place. We seek to mobilize this concept to \\ envision meaningful water policies and hydro-social practices to enhance social \\ equity and empowerment for urban communities.
}

Keywords: water governance, water security, urbanization, political ecology, uneven development, territory

Subject classification codes: include these here if the journal requires them

\section{Introduction}

One morning in October 2019, we crowded into a community center in a lower-income neighborhood in the southern metropolitan region of São Paulo. Located alongside the Billings reservoir, where a significant portion of the city's drinking water is stored, this neighborhood is reflective of a common urbanization process in the city. Roughly two decades ago, in response to continued in-migration and a lack of affordable housing for low-income residents, land developers with no intention of providing adequate infrastructure illegally sold the land to migrants from northeastern Brazil (Holston, 2009; Kowarick, 1979). This process of illegal selling and semi-formal occupation marks Brazilian urban history and has produced much of São Paulo’s current formespecially in its expansive peripheries. Members of the residents' association recounted their long struggle for water and sanitation services as they endeavored to develop and legalize their settlement. They told stories of multiple battles and negotiations with the municipal government and state water company, which finally culminated in the 
installation of water and sewerage pipes. Residents even dug trenches for the pipes and drainage in order to protect the near-by reservoir from untreated sewage.

Two elements stood out from this meeting: first, the physical and emotional labor spent on coping with inadequate water and sanitation services while attempting to secure access; and second, the community's emphasis on securing formal (state) networked infrastructure, both for quality of provision and the legal recognition it offered to secure their land rights. For these residents, living adjacent to the city's water supply had no bearing on their everyday experiences of water insecurity. Instead, their experiences offer insight into alternative modes of urban water security, those that are relational in terms of place, politics, and participation. Our intention is to draw on these exchanges in order to envision new ways of considering water security and insecurity.

Adequate water provision to urban centers is an ongoing challenge due to increasing urbanization and growing pressure on water resources (McDonald et al., 2011; 2014). Although water and sanitation coverage are generally higher in urban than rural areas in the Global South, this masks deficiencies in both the poorest urban areas and smaller settlements, and it overlooks that concentrated populations in urban areas necessitate shared infrastructure for water supply, waste disposal, and flood protection (Anand, 2017; Furlong \& Kooy, 2017; Kooy, 2014; Tomaz et al., 2020). Furthermore, while much attention is paid to the lack of access among lower-income populations (mainly in the Global South), more developed contexts (in the Global North and South) also face challenges of ageing infrastructure and high per-capita consumption (Clark, 2019; Morckel, 2017; Ranganathan, 2014). Both of these issues have led to the nature and scale of urban infrastructure and service provision being called into question.

The rise of the concept of water security, linked with the so-called 'global water crisis', has shifted emphasis towards long-term strategies for water management, often 
though supply-led solutions (Grey \& Sadoff, 2005). Focusing on the supply of water emphasizes the roles of external drivers in heightening water risks, and both neglects the unevenness of water risks and underplays their root causes (Loftus, 2015). By contrast, the concept of water security we propose demands that we incorporate the nature of water-society relations our analyses (Jepson et al., 2017). These relations include access to water, exposure to risks, and the cultural meanings of water. Therefore, in addition to water sources, we argue that relational water flows, infrastructure, governance, rights, and social action are also critical to urban water security.

The aim of this Viewpoint is to mobilize understandings of both water security and the urban as relational. Our intention is to set out a framework for water security that both examines the social relations that underpin water insecurity and goes beyond the urban as merely the context in which water provision and risk protection take place. By understanding urban water insecurities as produced through processes of urban development and governance, we frame urban water security as a process of transforming the relationship between urban dwellers and water provision to enhance social equity and empowerment. This means, for example, that urban water security should move away from prescribed policies that dictate what universal actions and actors should be, and towards political processes that directly engage and respond to the needs of urban dwellers themselves. Such reflection is the result of a workshop on Urban Water Security: from infrastructure to social action that took place at Universidade Federal do ABC - Brazil, and gathered young scholars developing research on water security in the cities of São Paulo, Rio de Janeiro, Cairo, Jacarta and Dhaka. The qualitative data that supports such reflection comes from research developed by the article's authors that took place between 2015 and 2019. 
Following this introduction, the next section sets out to conceptualize water security for urban contexts. Section 3 builds on this to develop an analytical framework for urban water security. In section 4 we conclude, highlighting how the relational urban water security framework presented and discussed in this article could contribute towards the principal of water as a right in practice.

\section{Urban Water Securities}

\section{The urbanization of water}

Urbanization can be understood as a process that enrols the biophysical landscape into processes of accumulation and agglomeration to produce new forms of socio-nature (Brenner \& Schmid, 2015; Cronon, 1991; Heynen et al., 2006; Seabra, 2018). The multiple ways in which water resources are enrolled into the process of urbanization have important implications for urban water security at different scales. For instance, the self-construction of housing and the self-provisioning of infrastructure that are commonly found in cities of the Global South entail distinct forms of social reproduction and labor, and produce distinct urban landscapes and socio-natural relations. As Maricato (1979) points out in the context of Brazilian metropolises, in the absence of an adequate state housing policy for lower-income groups, underpaid workers have no choice but to build their own homes, often on city peripheries. In these areas, the production of space goes beyond the auto-production of the house, to include other elements of the urban fabric. These include water and sewerage systems constructed either through self-dug wells or illegal connections to the mains, which often pass-through low-income areas without serving them (Ferrara, 2013).

These processes of auto-construction and other forms of bottom-up urbanization highlight the complex interplay between the dynamics of structure and agency in 
contemporary urban centers (Bhan, 2019; Caldeira, 2017). Transcending the binary between formal and informal, we place the production of space and nature across deeply divergent geographies at the center of a critical relational approach to urban water security. Here, a key component is understanding the urban political economy that underpins the (uneven) development of urban space, through the processes and relations that affect and shape land, water, infrastructure, and labor in any given urban context. In this way, we position water insecurity as inseparable from the broader global dynamics of inequality, center/periphery relationships, and the shifting and changing nature of capitalism (Harvey, 2007). Moreover, our approach acknowledges that cities are increasingly linked to the real estate sector and associated patterns of speculation and investment, where finance plays a central role in the contemporary production of space ( Fernandez \& Aalbers, 2020; Fields, 2017; Weber, 2010). This matters greatly for urban water security, as the rise of financialized real estate reconfigures land values and ownership, as well as infrastructure provisioning and regulation-often in ways that reinforce existing urban inequalities and further impede access to housing and infrastructure among low-income groups (Aalbers et al., 2020; Jorge, 2020; Wahby, 2019). These dynamics directly underpin the urban water insecurities that are documented by existing literature, yet which are typically framed in terms of problems to be solved by better technologies, policies, or institutional arrangements (e.g. Hoekstra et al., 2018).

\section{Rethinking water security for urban centers}

A number of definitions of water security exist in the literature, most of which reference conditions relating to the state of water that should be achieved in order for water security to be attained (Cook \& Bakker, 2012). In oft-cited examples, Grey and Sadoff (2005) refer to sufficient quantities of water and acceptable levels of risk, whereas the 
United Nations (2013) defines the specific criteria of adequate water quantity, quality, continuity, and affordability, in line with the Millennium Development Goals. These definitions of water security can be described as mainstream, because they focus on water as the object of analysis, as opposed to the human relations that underpin water insecurity (Loftus, 2015; Jepson et al., 2017).

In setting out a relational approach to water security, Jepson et al. (2017: 47) argue that, by framing water as a material resource, these definitions of water security direct attention towards interventions that produce or store water so as to alleviate scarcity, which serves to address the symptoms of water insecurity rather than its underlying causes. Jepson et al. instead emphasize the need for water security interventions that transform hydro-social relations in ways that enable people and organizations to engage in the political processes through which water is governed.

Most existing literature on urban water security follows mainstream water security frames. In this way, urban water security is commonly defined by supply risks associated with water scarcity and water quality across urban space (Allan et al., 2018; Brears, 2016; Hoekstra et al., 2018; Nazemi \& Madani, 2017). These perspectives hold that as urban growth increases and individual cities expand, water authorities and utilities continuously reconfigure their investment and planning strategies according to a vision of water security defined by continuous water supply to urban users for robust economic development (Padowski et al., 2016; Richter et al., 2013; Jaramillo \& Nazemi, 2018; Jensen \& Wu, 2018). Water is seen as an object to be captured, controlled, distributed, and drained, in order to minimize risk and maximize benefit to economic actors in towns and cities. Even in recent scholarship that has expanded urban water security beyond the narrow terms of economic development and considering ideas of ecological sustainability (Hoekstra et al., 2018; Zeitoun et al., 2016) or adaptation 
(Scott et al., 2013), water remains conceptualized as a material resource to be delivered to and managed in urban centres, rather than a socio-environmental relation (Allan et al., 2018).

This extension of mainstream water security frames to urban areas is problematic on two main levels. First, it takes the urban condition as merely the context or background to water security issues, and thus overlooks how urbanization processes have shaped and been shaped by water dynamics. The implications are such that water's value is seen simply as an input into the production of urban space and life, rather than as part of a more profound process of reconstituting nature embedded within urban processes. Second, far from technocratic, this mainstream framing of urban water security obscures how interventions play an important role in building the necessary political economic coalitions to determine who gets water, how, and through what legal and extra-legal means. This normative vision of urban water security, which is concerned with the physical supply of water, underpins and legitimizes the material, administrative, and political power that enables water insecurity to persist (Birkenholtz, 2016; Islar, 2012; Octavianti, 2019). Such dynamics demonstrate how infrastructure and institutional change can be leveraged to prioritize elite projects and capital accumulation to the detriment of social equity, leading to the question of what water security, and for whom?

Several scholars have provided new lines of analysis that incorporate relational thinking and multi-scalar visions to address the broader issue of urban water security for whom, taking into account the dynamic processes of fixity and flow in urban contexts (Ranagathan, 2014). On the one hand, Hommes et al. (2019) argue for new ways to think about urban water spaces as hydro-social territories, and in particular, rural-urban relations. The reconfiguration of hydro-social territories offer insights into the social 
power dynamics that are at play as water flows are reworked to move from rural to urban areas (see also Beckner et al., 2019). Others argue for embodied approaches to water, which attend to the flows of water to and through people's bodies (Sultana, 2011; Doshi, 2017; Truelove, 2019). This sheds greater light on how individual and collective experiences of water (in)security are refracted through a complex configuration of urban water practices and micro-politics, shaped by intersecting gender, class, and racial experiences. Focusing on the everyday lived experiences of urban water insecurity offers a way to critically examine the notion of 'universal' water access, as well as how this is shaped by broader power relations within the city. Taken together, there is momentum to build an understanding of a relational approach to urban water security that is attentive to the role of power in shaping how water flows through human bodies, practices, infrastructure, and institutions, within and across distinct urban centers worldwide.

Based on these directions, we develop a conceptual and analytical framework for a relational approach to urban water security that can be utilized in distinct contexts, where water is understood to exist within urban and institutional landscapes that flow between the formal and the informal, the public and the private, and the precarious and the stable. We advocate for an approach to urban water security that puts at its centre not only how people access water in urban spaces around the globe, but the ways human dignity is co-produced through fluid relations (Gimelli et al., 2018; Jepson et al., 2019; Mehta, 2014). In the remainder of this article, we reflect on how we understand the urban within urban water security, and what a recognition that political economy shapes urban water flows, infrastructure, institutions, practices and discourses means for a relational framing of urban water security. 


\section{Co-producing Secure Water Futures from Below}

Our conceptualization of urban water security moves away from describing the characteristics and challenges of water resources, services, and risks in urban centers, and instead attends to the urbanization of water-society relations. This concerns the political-economic processes through which water is enrolled into the production of urban space, and how this configures the ownership, production, distribution, and valuation of water at different scales and moments in any given urban context. Shedding light on uneven urban water security calls for attention to the role of power relations in shaping water resources and flows, with the goal of locating potential entry-points for contestation and change. This reframing enables a water politics that centers on securing and enhancing the social and cultural organizations, practices, and arguments through which citizens may be better equipped to contest the governance of urban water flows and services.

Understanding urban water security as the result of the urbanization of watersocial relations, we offer five entering points to reflect and to act towards urban water security processes in order to reshape the landscape of urban water insecurity and inequality in place: territory, labor relations and citizens' rights to the city, infrastructure, governance, and social action. First, understanding water security in a territorial perspective contributes to a new reading on how flows of power and dispute are in place in order to guarantee urban water security. We draw from a decolonial reading of territory aligned to a Global South perspective and different from the Anglophone vision that understands territory as political-economic and politicalstrategic relations tied to the sovereignty of the modern state (Halvorsen, 2019). In our framing, territories are spaces of struggle and resistance in response to an imposed development model since the Colonial period (Escobar, 2008; Moreano et al., 2017). 
Such understanding recognizes that different territories overlap in place and time and are the result of distinct multiscalar worldviews, with specific political strategies, rules, meanings and cultural practices. Such multiple territories can lead to situations of conflict, especially when social movements occupy or remake spaces, reinventing their meaning and uses in a decolonial frame (Haesbaert, 2007; Porto-Gonçalves, 2009).

The understanding of urban water security dialogues with the concept of hydrosocial territories as the constitution of socio-environmental and spatially bounded multiscalar networks activated to guarantee access to water (Boelens et al., 2016; Hommes et al., 2018). In this understanding, water security strategies could mobilize distinct hydrosocial territories, with specific social actors, networks, rules, technologies, infrastructure and practices to access water. A relational approach to urban water security would subsequently recognize multiple hydro-social territories as the result of multiscalar and multidimensional flows of water and power beyond watersheds and consider rural/urban relations as part of the processes that constitutes such new territories (Empinotti et al., 2021; Carmo \& Anazawa, 2017; Pires do Rio, 2017; Hommes \& Boelens, 2017; Bernabeu \& Martín, 2019).

The construction of hydro-social territories through urban water security is influenced by processes such as labor relations and citizens' rights to the city, our second point of entrance. Shifting forms of labor in cities plays are critical to understanding water security. As communities are forced into increased informal and precarious work, the cost and time spent to maintain, improve, and contest access to water fluctuates depending on a dynamic labor market and its relation to insecure tenure rights. These structural dimensions are rendered fluid as legislative, institutional, and socio-political contexts are interpreted and reimagined by the state, non-state actors, and communities. For instance, literature on infrastructure has demonstrated how informal 
residents can gain legal recognition by demanding physical connections to their settlements (Holston, 2009). Yet, as Anand (2017) also reminds us, access to physical infrastructure does not guarantee permanent tenure or access rights, and, in reality, many communities experience cyclical episodes of securing or losing rights as urban political economies and governance regimes change.

If such struggles for water are spatialized through territories, labor relations and citizens' rights to the city; it also materializes through infrastructure, our third point of entrance. The economic importance of urban areas, combined with the growing demand for water by cities that often exceeds the resources within their boundaries, have been used to justify supply-led approaches oriented around infrastructure, especially with increased emphases on scarcity as the key issue (Crow-Miller et al., 2017). Securing water at the city level does not necessarily increase water security at the household level, however. Moreover, defining 'access' in practice needs care: even if low-income households have water connections, many experience intermittent supply, low water pressure, and inability to pay bills (Rodina, 2016). These conditions give rise to forms of heterogeneous off-grid infrastructures that are found in cities globally (Vandewalle \& Jepson, 2015; Deitz \& Meehan, 2019). To better understand the key relations that produce urban water security, it is necessary to think and plan beyond those who are connected to formal public services.

Furthermore, it is largely institutional arrangements and governance processes that determine access to (formal) infrastructure, which, as above, is often minimal for those living in low-income settlements. Such assumption leads to our fourth entrance point: water governance practices. The formation of institutional landscapes of water governance is a consequence of urbanization processes that encompasses water control and leads to particular political economic relations, which in turn determine by whom 
and how water is controlled, produced, and distributed in urban areas (Bakker \& Morinville, 2013). While some authors focus on the nature of governance for water security, emphasizing institutional modalities modalities and the principles of 'good governance' as the pathway towards water security, this can overlook how governance choices are shaped by power relations and politics (Bakker \& Morinville, 2013; Empinotti et al., 2019).

From a relational standpoint, the object of water governance is not water itself, but the relationship between water and people, in terms of who can access water and under what conditions. It is, thus, important to move beyond the format of decisionmaking frameworks and procedures for water and attend to the role of power relations in producing water governance arrangements that in turn shape water-society relations (Jepson et al., 2017). Such governance shifts in urban contexts include neoliberalization (e.g. privatization), rescaling (e.g. decentralization), and regulation (e.g. formalisation) of water provision, which have been promoted as pragmatic responses to improve water governance, but have often served the agendas of political power and capital accumulation more than the interests of urban water consumers (Empinotti et al., 2019). Therefore, a critical framework for urban water security should reveal the unequal power relations embedded in urban water governance structures and processes in order to define entry-points to contest these through political engagements and mobilizations.

Based on that, it is key that institutions and water governance practices involve the mobilization and participation of a diversity of social actors in co-producing solutions. The role of the state would be to guarantee water access to all, even under a water pricing system. How should be done? This question leads to our fifth entering point: social action. We understand that social action comes from civil society organizations, potentially balancing state and private sector agendas in the institutional 
practices of governance. Social participation is understood to be present not just in formal spaces of participation but also in neighborhood associations and other types of movements. In this sense, participatory processes go beyond negotiation practices and the finding of common agreements and instead include potentially innovative solutions to water access co-produced by different bodies of knowledge and praxis (Edelenbos et al., 2011). In this regard, co-production of knowledge can be seen as an opportunity to embed the creative and imaginative wisdom of diverse stakeholders into the processes of water security.

Directing attention towards social action and mobilization for water security enables us to capture how residents act collectively to obtain, manage, and maintain water (and other) services in a context of land, housing tenure, social, financial and environmental insecurity. In this sense, attention to social mobilization and action reflects the fact that "culturally-shared views of water fundamentally shape people's understanding and experiences of water security" (Jepson et al., 2017; Wantzen, 2016). Attention to knowledge co-production and social action could lead to the creation of more sustainable and socially informed infrastructures and practices that cultivate and are cultivated by lived experiences with water. Strengthening people's bonds to the elements of nature that provide ecosystemic and cultural services can improve the quality of life of vulnerable communities, society in general, and the biophysical environment.

\section{Conclusion}

Theorizing urban water security as a relational process contributes to a new water culture based on social engagement, co-production of knowledge, and attention to power and how it is materialized. Attention to urban water security asks us to focus on how we use water, who benefits from it, who is excluded, and how to these exclusions 
can be remedied. Social engagement and co-production are critical to achieving relational water security, which recognizes hydro-social relations that mediate the conditions of water's materiality within ecosystems, political equality, and human wellbeing. We suggest that attention to urban water security must go beyond the use of percentage rates to measure access to water and infrastructure. Infrastructure is important but is not the only indicator of success. Instead, monitoring infrastructure should be part of a broader approach that prioritizes the social relations that underpin water insecurity and goes beyond the urban as merely the context in which water provision and risk take place. We seek to mobilize this concept to envision meaningful water policies and hydro-social practices to enhance social equity and empowerment for urban communities. This is a shift from the sectorial and fragmented perspective towards a territorial approach. The understanding of a relational urban water security as the result of interrelations and intersections though the processes of urbanization could lead to equality and justice in water access, putting in practice the principal of water access as a right.

\section{References}

Aalbers, M. B., Rolnik, R., \& Krijnen, M. (2020). The Financialization of Housing in Capitalism's Peripheries. Housing Policy Debate, 30(4), 481-485. https://doi.org/10.1080/10511482.2020.1783812

Allan, J. V., Kenway, S. J., \& Head, B. W. (2018). Urban water security-What does it mean? Urban Water Journal, 15(9), 899-910. https://doi.org/10.1080/1573062X.2019.1574843 
Anand, N. (2017). Hydraulic City: Water and the Infrastructures of Citizenship in Mumbai (p. dup;9780822373599/1). Duke University Press. https://doi.org/10.1215/9780822373599

Bakker, K., \& Morinville, C. (2013). The governance dimensions of water security: A review. Philosophical Transactions of the Royal Society A: Mathematical, Physical and Engineering Sciences, 371(2002), 20130116. https://doi.org/10.1098/rsta.2013.0116

Beckner, S., Jepson, W., Brannstrom, C., \& Tracy, J. (2019). 'The San Antonio River Doesn't Start in San Antonio, It Now Starts in Burleson County': Stakeholder Perspectives on a Groundwater Transfer Project in Central Texas. Society \& Natural Resources, 32(11), 1222-1238. https://doi.org/10.1080/08941920.2019.1648709

Bernabeu, M.M., \&Martín, F. (2019). El periurbano recreado. Urbanizaciones cerradas como $\underline{\text { nuevos hídricos en el paisage hídrico del área Metropolitana de Mendonza, Argentina. }}$ Quid, 16(11), 55-85.

Birkenholtz, T. (2016). Dispossessing irrigators: Water grabbing, supply-side growth and farmer resistance in India. Geoforum, 69, 94-105. https://doi.org/10.1016/j.geoforum.2015.12.014

Bhan, G. (2019). Notes on a Southern urban practice. Environment and Urbanization, 31(2), 639-654.

Boelens, R., Hoogesteger, J., Swyngedouw, E., Vos, J., \& Wester, P. (2016). Hydrosocial territories: A political ecology perspective. Water International, 41(1), 1-14. https://doi.org/10.1080/02508060.2016.1134898

Brears, R. C. (2016). Urban water security. John Wiley \& Sons.

Brenner, N., \& Schmid, C. (2015). Towards a new epistemology of the urban?. City, 19(2-3), $151-182$.

Budds, J. (2019). Geoforum, 98, 
Caldeira, T. P. (2017). Peripheral urbanization: Autoconstruction, transversal logics, and politics in cities of the global south. Environment and Planning D: Society and Space, 35(1), 3-20.

Cardone, R., \& Fonseca, C. (2006). Water Sector in Small Urban Centres: Analysis of donor flows to water supply and sanitation services (No. 2; UN-Habitat Report on the Water Sector in Small Urban Centres). UN-Habitat (United Nations Human Settlements Programme).

Carmo, R. L. do, \& Anazawa, T. M. (2017). Hidromegalópole São Paulo-Rio de Janeiro: Escassez hídrica, sobreposição de espacialidades e conflitos.

Clark, C. (2019). Race, austerity and water justice in the United States: Fighting for the human right to water in Detroit and Flint, Michigan. In Water politics: Governance, justice and the right to water (pp. 175-188). Routledge.

Cook, C., \& Bakker, K. (2012). Water security: Debating an emerging paradigm. Global environmental change, 22(1), 94-102.

Cronon, W. (2009). Nature's metropolis: Chicago and the Great West. WW Norton \& Company.

Crow-Miller, B., Webber, M., \& Molle, F. (2017). The (re) turn to infrastructure for water management?. Water Alternatives.

Deitz, S., \& Meehan, K. (2019). Plumbing Poverty: Mapping Hot Spots of Racial and Geographic Inequality in U.S. Household Water Insecurity. Annals of the American Association of Geographers, 109(4), 1092-1109. https://doi.org/10.1080/24694452.2018.1530587

Doshi, S. (2017). Embodied urban political ecology: Five propositions. Area, 49(1), 125-128. 
Edelenbos, J., Van Buuren, A., \& van Schie, N. (2011). Co-producing knowledge: joint knowledge production between experts, bureaucrats and stakeholders in Dutch water management projects. Environmental science \& policy, 14(6), 675-684.

Empinotti, V. L., Budds, J., \& Aversa, M. (2019). Governance and water security: The role of the water institutional framework in the 2013-15 water crisis in São Paulo, Brazil. Geoforum, 98, 46-54. https://doi.org/10.1016/j.geoforum.2018.09.022

Empinotti, V. L., Tadeu, N. D., Fragkou, M. C., \& Sinisgalli, P. A. (2021). Desafios da governança da água: A contribuição do conceito de territórios hidrossociais para novos arranjos intitucionais. Estudos Avançados.

Escobar, A. (2008). Territories of difference: Place, movements, life, redes. Duke University Press.

Fernández, M. M. B., \& García, F. M. (2019). El periurbano recreado. Urbanizaciones cerradas como nuevos híbridos en el paisaje hídrico del Área Metropolitana de Mendoza, Argentina. Quid 16. Revista del Área de Estudios Urbanos, O(11), 55-85.

Fernandez, R., \& Aalbers, M. B. (2020). Housing Financialization in the Global South: In Search of a Comparative Framework. Housing Policy Debate, 30(4), 680-701. https://doi.org/10.1080/10511482.2019.1681491

Ferrara, L. N. (2013). Urbanização da natureza: da autoprovisão de infraestruturas aos projetos de recuperação ambiental nos mananciais do sul da metrópole paulistana. (Doctoral dissertation, University of São Paulo) doi:10.11606/T.16.2013.tde-25092013-110858.

Fields, D. (2017). Urban struggles with financialization. Geography Compass, 11(11), e12334. https://doi.org/10.1111/gec3.12334 
Furlong, K., \& Kooy, M. (2017). Worlding Water Supply: Thinking Beyond the Network in Jakarta. International Journal of Urban and Regional Research, 41(6), 888-903. https://doi.org/10.1111/1468-2427.12582

Gimelli, F. M., Bos, J. J., \& Rogers, B. C. (2018). Fostering equity and wellbeing through water: A reinterpretation of the goal of securing access. World Development, 104(C), 19.

Grey, D., \& Sadoff, C. (2005). Water resources, growth and development. Prepared for the Panel of Finance Ministers, the UN Commission for Sustainable Development.

Haesbaert, R. (2007). Território e multiterritorialidade: Um debate. GEOgraphia, 9(17), Article 17. https://doi.org/10.22409/GEOgraphia2007.v9i17.a13531

Halvorsen, S. (2019). Decolonising territory: Dialogues with Latin American knowledges and grassroots strategies. Progress in Human Geography, 43(5), 790-814. https://doi.org/10.1177/0309132518777623

Harvey, D. (2007). A brief history of neoliberalism. Oxford University Press, USA.

Heynen, N., Kaika, M., \& Swyngedouw, E. (Eds.). (2006). In the nature of cities: urban political ecology and the politics of urban metabolism. Taylor \& Francis.

Hoekstra, A. Y., Buurman, J., \& Ginkel, K. C. H. van. (2018). Urban water security: A review. Environmental Research Letters, 13(5), 053002. https://doi.org/10.1088/17489326/aaba52

Hommes, L., Boelens, R., Harris, L. M., \& Veldwisch, G. J. (2019). Rural-urban water struggles: Urbanizing hydrosocial territories and evolving connections, discourses and identities. Water International, 44(2), 81-94.

https://doi.org/10.1080/02508060.2019.1583311 
Hommes, L. M., Boelens, R. A., Abadia, B. D., Hidalgo, J. P., \& Dijk, J. D. H. van. (2018). Reconfiguration of Hydrosocial Territories and Struggles for Water Justice: From Part II - Hydrosocial De-Patterning and Re-Composition. Water Justice, 151-168.

Hommes, L., \& Boelens, R. (2017). Urbanizing rural waters: Rural-urban water transfers and the reconfiguration of hydrosocial territories in Lima. Political Geography, 57, 71-80. https://doi.org/10.1017/9781316831847.010

Holston, J. (2009). Insurgent citizenship: Disjunctions of democracy and modernity in Brazil. Princeton university press.

Islar, M. (2012). Privatised hydropower development in Turkey: A case of water grabbing? Water Alternatives, 5(2), 376-391.

Jaramillo, P., \& Nazemi, A. (2018). Assessing urban water security under changing climate: Challenges and ways forward. Sustainable Cities and Society, 41, 907-918. https://doi.org/10.1016/j.scs.2017.04.005

Jensen, O., \& Wu, H. (2018). Urban water security indicators: Development and pilot. Environmental Science \& Policy, 83, 33-45. https://doi.org/10.1016/j.envsci.2018.02.003

Jepson, W., \& Vandewalle, E. (2016). Household Water Insecurity in the Global North: A Study of Rural and Periurban Settlements on the Texas-Mexico Border. The Professional Geographer, 68(1), 66-81. https://doi.org/10.1080/00330124.2015.1028324

Jepson, W., Budds, J., Eichelberger, L., Harris, L., Norman, E., O'Reilly, K., Pearson, a.; Shah, J., Shinn, J., Staddon, C., Stoler, J., Wutich, A. \& Young, S. (2017). Advancing human capabilities for water security: A relational approach. Water Security, 1, 46-52. Jepson, W., Wutich, A., \& Harris, L. M. (2019). Water-security capabilities and the human right to water. Water Politics: Governance, Justice and the Right to Water, 84. 
Jorge, S. (2020). The Financialization of the Margins of Maputo, Mozambique. Housing Policy Debate, 30(4), 606-622.

Kooy, M. (2014). Developing Informality: The Production of Jakarta's Urban Waterscape. Water Alternatives, 7, 35-53.

Kowarick, L. (1979). A espoliação urbana (Vol. 44). Editora Paz e Terra.

Loftus, A. (2015). Water (in) security: Securing the right to water. The Geographical Journal, 181(4), 350-356.

Maricato, E. (1979). A produção capitalista da casa (e da cidade) no Brasil industrial (Vol. 1). Editora Alfa-Omega.

McDonald, R. I., Douglas, I., Revenga, C., Hale, R., Grimm, N., Grönwall, J., \& Fekete, B. (2011). Global urban growth and the geography of water availability, quality, and delivery. Ambio, 40(5), 437-446. https://doi.org/10.1007/s13280-011-0152-6

McDonald, R. I., Weber, K., Padowski, J., Flörke, M., Schneider, C., Green, P. A., Gleeson, T., Eckman, S., Lehner, B., Balk, D., Boucher, T., Grill, G., \& Montgomery, M. (2014). Water on an urban planet: Urbanization and the reach of urban water infrastructure. Global Environmental Change, 27, 96-105. https://doi.org/10.1016/j.gloenvcha.2014.04.022

Mehta, L. (2014). Water and Human Development. https://doi.org/10.1016/j.worlddev.2013.12.018

Morckel, V. (2017). Why the Flint, Michigan, USA water crisis is an urban planning failure. Cities, 62, 23-27. https://doi.org/10.1016/j.cities.2016.12.002

Moreano, M., Francisco, M., \& Bryant, R. (2017). Hacia una ecología política global: Aportes desde el sur. Ecología Política Latinoamericana. Pensamiento Crítico, Diferencia Latinoamericana y Rearticulación Epistémica, 1, 197-212. 
Nazemi, A., \& Madani, K. (2017). Urban water security: Emerging discussion and remaining challenges. https://doi.org/10.1016/J.SCS.2017.09.011

Octavianti, T. (2019). De-and Re-politicisation of Water Security as Examined Through the Lens of the Hydrosocial Cycle: The Case of Jakarta's Sea Wall Plan. Water Alternatives, 12(3).

Padowski, J. C., Carrera, L., \& Jawitz, J. W. (2016). Overcoming Urban Water Insecurity with Infrastructure and Institutions. Water Resources Management: An International Journal, Published for the European Water Resources Association (EWRA), 30(13), $4913-4926$.

Pires do Rio, G. (2017). ÁGUA: URGÊNCIA DE UMA AGENDA TERRITORIAL. Ambiente \& Sociedade, XIX, 105.

Porto-Gonçalves, C. W. (2009). De Saberes y de Territorios—Diversidad y emancipación a partir de la experiencia latino-americana. Polis. Revista Latinoamericana, 22, Article 22. http://journals.openedition.org/polis/2636

Ranganathan, M. (2014). Paying for Pipes, Claiming Citizenship: Political Agency and Water Reforms at the Urban Periphery. International Journal of Urban and Regional Research, 38(2), 590-608. https://doi.org/10.1111/1468-2427.12028

Richter, B. D., Abell, D., Bacha, E., Brauman, K., Calos, S., Cohn, A., Disla, C., O’Brien, S. F., Hodges, D., Kaiser, S., Loughran, M., Mestre, C., Reardon, M., \& Siegfried, E. (2013). Tapped out: How can cities secure their water future? Water Policy, 15(3), 335363. https://doi.org/10.2166/wp.2013.105

Rodina, L. (2016). Human right to water in Khayelitsha, South Africa-Lessons from a 'lived experiences' perspective. Geoforum, 72(2016), 58-66.

Scott, C. A., Meza, F. J., Varady, R. G., Tiessen, H., McEvoy, J., Garfin, G. M., Wilder, M., Farfán, L. M., Pablos, N. P., \& Montaña, E. (2013). Water Security and Adaptive 
Management in the Arid Americas. Annals of the Association of American

Geographers, 103(2), 280-289. https://doi.org/10.1080/00045608.2013.754660

Seabra, O. C. de L. (2018). Bacia do Alto Tietê: A montagem do sistema hidrelétrico de São Paulo e sua problemática. Boletim Paulista de Geografia, O(100), 56-84.

Sultana, F. (2011). Suffering for water, suffering from water: Emotional geographies of resource access, control and conflict. Geoforum, 42(2), 163-172. https://doi.org/10.1016/j.geoforum.2010.12.002

Tomaz, P., Jepson, W., \& Santos, J. de O. (2020). Urban Household Water Insecurity from the Margins: Perspectives from Northeast Brazil. The Professional Geographer, 72(4), 481-498.

Truelove, Y. (2019). Rethinking water insecurity, inequality and infrastructure through an embodied urban political ecology. WIREs Water, 6(3), e1342. https://doi.org/10.1002/wat2.1342

United Nations. (2013). Water Security \& the Global Water Agenda. Ontario, UNU-

\section{INEWH, 47.}

Vandewalle, E., \& Jepson, W. (2015). Mediating water governance: Point-of-use water filtration devices for low-income communities along the US-Mexico border. Geo: Geography and Environment, 2(2), 107-121. https://doi.org/10.1002/geo2.9

Wahby, N. (2019). The role of the state in urban development: the case of urban waterscapes in Cairo, Egypt (Doctoral dissertation, University of Cambridge).

Wantzen, K.M., Ballouche, A., Longuet, I., Bao, I., Bocoun, H., Cissé, L., Chauhan, M., Girard, P., Gopal, B., Kane, A., Marchese, M.R., Nautiyal, P. Teixeira, P. \& Zalewski, M. (2016). River Culture: an eco-social approach to mitigate the biological and cultural diversity crisis in riverscapes. Ecohydrology \& Hydrobiology, 16(1), 7-18. https://doi.org/10.1016/j.ecohyd.2015.12.003 
Weber, R. (2010). Selling City Futures: The Financialization of Urban Redevelopment Policy. Economic Geography, 86(3), 251-274. https://doi.org/10.1111/j.1944$\underline{8287.2010 .01077 . x}$

Zeitoun, M., Lankford, B., Krueger, T., Forsyth, T., Carter, R., Hoekstra, A. Y., Taylor, R., Varis, O., Cleaver, F., Boelens, R., Swatuk, L., Tickner, D., Scott, C. A., Mirumachi, N., \& Matthews, N. (2016). Reductionist and integrative research approaches to complex water security policy challenges. Global Environmental Change, 39, 143-154. https://doi.org/10.1016/j.gloenvcha.2016.04.010 


\title{
Advancing urban water security: The urbanization of water-society relations and entry-points for political engagement
}

\author{
Vanessa Lucena Empinotti \\ Engineering, Modelling and Applied Social Science Center, Federal University of ABC, \\ São Bernardo do Campo, Brazil \\ Jessica Budds
}

School of International Development, University of East Anglia, Norwich, UK

Wendy Jepson

Geography Department, Texas A\&M University, College Station, US

Nate Millington

Geography Department, University of Manchester, Manchester, UK

Luciana Nicolau Ferrara

Engineering, Modelling and Applied Social Science Center, Federal University of ABC, São Bernardo do Campo, Brazil

Jo-Anee Geere

School of Health Sciences, University of East Anglia, Norwich, UK

Edson Grandisoli

Advance Studies Institute, University of São Paulo, São Paulo, Brazil

Mariana Gutierres Arteiro da Paz

Center for Earth System Science, National Institute for Space Research, São José dos Campos, Brazil 


\section{Bruno Peregrina Puga}

Institute of Economics, State University of Campinas, Campinas, Brazil

Estela Macedo Alves

Institute of Energy and Environment, University of São Paulo, São Paulo, Brazil

Sally Cawood

Department of Urban Studies and Planning, University of Sheffield, Sheffield, UK

Pedro Roberto Jacobi

Institute of Energy and Environment, University of São Paulo, São Paulo, Brazil

Victor Uehara Kinjo

Advance Studies Institute, University of São Paulo, São Paulo, Brazil

Andrea Lampis

Institute of Energy and Environment, University of São Paulo, São Paulo, Brazil

Ricardo Moretti

Engineering, Modelling and Applied Social Science Center, Federal University of ABC, São Bernardo do Campo, Brazil

Thanti Octavianti

Center of Water, Cities and Resillience, University of West England, Bristol, UK

Natalia Periotto

Environmental Sciences Department, Federal University of São Carlos, São Carlos, Brazil

Ruth Quinn 
Department of Civil and Structural Engineering, University of Sheffield, Sheffield, UK

\section{Suyá Quintslr}

Urban and Regional Planning Institute, Federal University of Rio de Janeiro, Rio de Janeiro, Brazil

\section{Samia Sulaiman}

Engineering, Modelling and Applied Social Science Center, Federal University of ABC, São Bernardo do Campo, Brazil

\section{Paula Arce Vicente}

Engineering Department, University of Exeter, Exeter, UK

\section{Noura Wahby}

Department of Public Policy and Administration, American University in Cairo, Cairo, Egypt

Rua Acturus, 03, Jardim Antares, Bloco Delta, Room 309, 09606-070, São Bernardo do Campo, São Paulo, Brazil, v.empinotti@ufabc.edu.br

Acknowledgements:

We would like to thank the São Paulo Research State Foundation (FAPESP) and the British Council for your support through the following fundings: BNRL Urban Water Security in Brazil from Infrastructure to Social Action 2018/50088-5 and 2015/03804-9. 


\title{
Advancing urban water security: The urbanization of water-society relations and entry-points for political engagement
}

\author{
We seek to advance a critical and relational concept of urban water security that \\ theorizes urban processes in relation to the hydro-social dynamics that produce \\ experiences of water securities and insecurities at multiple scales. Our intention is \\ to set out an analytical framework that both examines the social relations that \\ underpin water insecurity and goes beyond the urban as merely the context in \\ which water provision and risk take place. We seek to mobilize this concept to \\ envision meaningful water policies and hydro-social practices to enhance social \\ equity and empowerment for urban communities.
}

Keywords: water governance, water security, urbanization, political ecology, uneven development, territory

Subject classification codes: include these here if the journal requires them

\section{Introduction}

One morning in October 2019, we crowded into a community center in a lower-income neighborhood in the southern metropolitan region of São Paulo. Located alongside the Billings reservoir, where a significant portion of the city's drinking water is stored, this neighborhood is reflective of a common urbanization process in the city. Roughly two decades ago, in response to continued in-migration and a lack of affordable housing for low-income residents, land developers with no intention of providing adequate infrastructure illegally sold the land to migrants from northeastern Brazil (Holston, 2009; Kowarick, 1979). This process of illegal selling and semi-formal occupation marks Brazilian urban history and has produced much of São Paulo's current formespecially in its expansive peripheries. Members of the residents' association recounted their long struggle for water and sanitation services as they endeavored to develop and legalize their settlement. They told stories of multiple battles and negotiations with the municipal government and state water company, which finally culminated in the 
installation of water and sewerage pipes. Residents even dug trenches for the pipes and drainage in order to protect the near-by reservoir from untreated sewage.

Two elements stood out from this meeting: first, the physical and emotional labor spent on coping with inadequate water and sanitation services while attempting to secure access; and second, the community's emphasis on securing formal (state) networked infrastructure, both for quality of provision and the legal recognition it offered to secure their land rights. For these residents, living adjacent to the city's water supply had no bearing on their everyday experiences of water insecurity. Instead, their experiences offer insight into alternative modes of urban water security, those that are relational in terms of place, politics, and participation. Our intention is to draw on these exchanges in order to envision new ways of considering water security and insecurity.

Adequate water provision to urban centers is an ongoing challenge due to increasing urbanization and growing pressure on water resources (McDonald et al., 2011; 2014). Although water and sanitation coverage are generally higher in urban than rural areas in the Global South, this masks deficiencies in both the poorest urban areas and smaller settlements, and it overlooks that concentrated populations in urban areas necessitate shared infrastructure for water supply, waste disposal, and flood protection (Anand, 2017; Furlong \& Kooy, 2017; Kooy, 2014; Tomaz et al., 2020). Furthermore, while much attention is paid to the lack of access among lower-income populations (mainly in the Global South), more developed contexts (in the Global North and South) also face challenges of ageing infrastructure and high per-capita consumption (Clark, 2019; Morckel, 2017; Ranganathan, 2014). Both of these issues have led to the nature and scale of urban infrastructure and service provision being called into question.

The rise of the concept of water security, linked with the so-called 'global water crisis', has shifted emphasis towards long-term strategies for water management, often 
though supply-led solutions (Grey \& Sadoff, 2005). Focusing on the supply of water emphasizes the roles of external drivers in heightening water risks, and both neglects the unevenness of water risks and underplays their root causes (Loftus, 2015). By contrast, the concept of water security we propose demands that we incorporate the nature of water-society relations our analyses (Jepson et al., 2017). These relations include access to water, exposure to risks, and the cultural meanings of water. Therefore, in addition to water sources, we argue that relational water flows, infrastructure, governance, rights, and social action are also critical to urban water security.

The aim of this Viewpoint is to mobilize understandings of both water security and the urban as relational. Our intention is to set out a framework for water security that both examines the social relations that underpin water insecurity and goes beyond the urban as merely the context in which water provision and risk protection take place. By understanding urban water insecurities as produced through processes of urban development and governance, we frame urban water security as a process of transforming the relationship between urban dwellers and water provision to enhance social equity and empowerment. This means, for example, that urban water security should move away from prescribed policies that dictate what universal actions and actors should be, and towards political processes that directly engage and respond to the needs of urban dwellers themselves. Such reflection is the result of a workshop on Urban Water Security: from infrastructure to social action that took place at Universidade Federal do ABC - Brazil, and gathered young scholars developing research on water security in the cities of São Paulo, Rio de Janeiro, Cairo, Jacarta and Dhaka. The qualitative data that supports such reflection comes from research developed by the article's authors that took place between 2015 and 2019. 
Following this introduction, the next section sets out to conceptualize water security for urban contexts. Section 3 builds on this to develop an analytical framework for urban water security. In section 4 we conclude, highlighting how the relational urban water security framework presented and discussed in this article could contribute towards the principal of water as a right in practice.

\section{Urban Water Securities}

\section{The urbanization of water}

Urbanization can be understood as a process that enrols the biophysical landscape into processes of accumulation and agglomeration to produce new forms of socio-nature (Brenner \& Schmid, 2015; Cronon, 1991; Heynen et al., 2006; Seabra, 2018). The multiple ways in which water resources are enrolled into the process of urbanization have important implications for urban water security at different scales. For instance, the self-construction of housing and the self-provisioning of infrastructure that are commonly found in cities of the Global South entail distinct forms of social reproduction and labor, and produce distinct urban landscapes and socio-natural relations. As Maricato (1979) points out in the context of Brazilian metropolises, in the absence of an adequate state housing policy for lower-income groups, underpaid workers have no choice but to build their own homes, often on city peripheries. In these areas, the production of space goes beyond the auto-production of the house, to include other elements of the urban fabric. These include water and sewerage systems constructed either through self-dug wells or illegal connections to the mains, which often pass-through low-income areas without serving them (Ferrara, 2013).

These processes of auto-construction and other forms of bottom-up urbanization highlight the complex interplay between the dynamics of structure and agency in 
contemporary urban centers (Bhan, 2019; Caldeira, 2017). Transcending the binary between formal and informal, we place the production of space and nature across deeply divergent geographies at the center of a critical relational approach to urban water security. Here, a key component is understanding the urban political economy that underpins the (uneven) development of urban space, through the processes and relations that affect and shape land, water, infrastructure, and labor in any given urban context. In this way, we position water insecurity as inseparable from the broader global dynamics of inequality, center/periphery relationships, and the shifting and changing nature of capitalism (Harvey, 2007). Moreover, our approach acknowledges that cities are increasingly linked to the real estate sector and associated patterns of speculation and investment, where finance plays a central role in the contemporary production of space ( Fernandez \& Aalbers, 2020; Fields, 2017; Weber, 2010). This matters greatly for urban water security, as the rise of financialized real estate reconfigures land values and ownership, as well as infrastructure provisioning and regulation-often in ways that reinforce existing urban inequalities and further impede access to housing and infrastructure among low-income groups (Aalbers et al., 2020; Jorge, 2020; Wahby, 2019). These dynamics directly underpin the urban water insecurities that are documented by existing literature, yet which are typically framed in terms of problems to be solved by better technologies, policies, or institutional arrangements (e.g. Hoekstra et al., 2018).

\section{Rethinking water security for urban centers}

A number of definitions of water security exist in the literature, most of which reference conditions relating to the state of water that should be achieved in order for water security to be attained (Cook \& Bakker, 2012). In oft-cited examples, Grey and Sadoff (2005) refer to sufficient quantities of water and acceptable levels of risk, whereas the 
United Nations (2013) defines the specific criteria of adequate water quantity, quality, continuity, and affordability, in line with the Millennium Development Goals. These definitions of water security can be described as mainstream, because they focus on water as the object of analysis, as opposed to the human relations that underpin water insecurity (Loftus, 2015; Jepson et al., 2017).

In setting out a relational approach to water security, Jepson et al. (2017: 47) argue that, by framing water as a material resource, these definitions of water security direct attention towards interventions that produce or store water so as to alleviate scarcity, which serves to address the symptoms of water insecurity rather than its underlying causes. Jepson et al. instead emphasize the need for water security interventions that transform hydro-social relations in ways that enable people and organizations to engage in the political processes through which water is governed.

Most existing literature on urban water security follows mainstream water security frames. In this way, urban water security is commonly defined by supply risks associated with water scarcity and water quality across urban space (Allan et al., 2018; Brears, 2016; Hoekstra et al., 2018; Nazemi \& Madani, 2017). These perspectives hold that as urban growth increases and individual cities expand, water authorities and utilities continuously reconfigure their investment and planning strategies according to a vision of water security defined by continuous water supply to urban users for robust economic development (Padowski et al., 2016; Richter et al., 2013; Jaramillo \& Nazemi, 2018; Jensen \& Wu, 2018). Water is seen as an object to be captured, controlled, distributed, and drained, in order to minimize risk and maximize benefit to economic actors in towns and cities. Even in recent scholarship that has expanded urban water security beyond the narrow terms of economic development and considering ideas of ecological sustainability (Hoekstra et al., 2018; Zeitoun et al., 2016) or adaptation 
(Scott et al., 2013), water remains conceptualized as a material resource to be delivered to and managed in urban centres, rather than a socio-environmental relation (Allan et al., 2018).

This extension of mainstream water security frames to urban areas is problematic on two main levels. First, it takes the urban condition as merely the context or background to water security issues, and thus overlooks how urbanization processes have shaped and been shaped by water dynamics. The implications are such that water's value is seen simply as an input into the production of urban space and life, rather than as part of a more profound process of reconstituting nature embedded within urban processes. Second, far from technocratic, this mainstream framing of urban water security obscures how interventions play an important role in building the necessary political economic coalitions to determine who gets water, how, and through what legal and extra-legal means. This normative vision of urban water security, which is concerned with the physical supply of water, underpins and legitimizes the material, administrative, and political power that enables water insecurity to persist (Birkenholtz, 2016; Islar, 2012; Octavianti, 2019). Such dynamics demonstrate how infrastructure and institutional change can be leveraged to prioritize elite projects and capital accumulation to the detriment of social equity, leading to the question of what water security, and for whom?

Several scholars have provided new lines of analysis that incorporate relational thinking and multi-scalar visions to address the broader issue of urban water security for whom, taking into account the dynamic processes of fixity and flow in urban contexts (Ranagathan, 2014). On the one hand, Hommes et al. (2019) argue for new ways to think about urban water spaces as hydro-social territories, and in particular, rural-urban relations. The reconfiguration of hydro-social territories offer insights into the social 
power dynamics that are at play as water flows are reworked to move from rural to water, which attend to the flows of water to and through people's bodies (Sultana, 2011; Doshi, 2017; Truelove, 2019). This sheds greater light on how individual and collective experiences of water (in)security are refracted through a complex configuration of urban water practices and micro-politics, shaped by intersecting gender, class, and racial experiences. Focusing on the everyday lived experiences of urban water insecurity offers a way to critically examine the notion of 'universal' water access, as well as how this is shaped by broader power relations within the city. Taken together, there is momentum to build an understanding of a relational approach to urban water security that is attentive to the role of power in shaping how water flows through human bodies, practices, infrastructure, and institutions, within and across distinct urban centers worldwide.

Based on these directions, we develop a conceptual and analytical framework for a relational approach to urban water security that can be utilized in distinct contexts, where water is understood to exist within urban and institutional landscapes that flow between the formal and the informal, the public and the private, and the precarious and the stable. We advocate for an approach to urban water security that puts at its centre not only how people access water in urban spaces around the globe, but the ways human dignity is co-produced through fluid relations (Gimelli et al., 2018; Jepson et al., 2019; Mehta, 2014). In the remainder of this article, we reflect on how we understand the urban within urban water security, and what a recognition that political economy shapes urban water flows, infrastructure, institutions, practices and discourses means for a relational framing of urban water security. 


\section{Co-producing Secure Water Futures from Below}

Our conceptualization of urban water security moves away from describing the characteristics and challenges of water resources, services, and risks in urban centers, and instead attends to the urbanization of water-society relations. This concerns the political-economic processes through which water is enrolled into the production of urban space, and how this configures the ownership, production, distribution, and valuation of water at different scales and moments in any given urban context. Shedding light on uneven urban water security calls for attention to the role of power relations in shaping water resources and flows, with the goal of locating potential entry-points for contestation and change. This reframing enables a water politics that centers on securing and enhancing the social and cultural organizations, practices, and arguments through which citizens may be better equipped to contest the governance of urban water flows and services.

Understanding urban water security as the result of the urbanization of watersocial relations, we offer five entering points to reflect and to act towards urban water security processes in order to reshape the landscape of urban water insecurity and inequality in place: territory, labor relations and citizens' rights to the city, infrastructure, governance, and social action. First, understanding water security in a territorial perspective contributes to a new reading on how flows of power and dispute are in place in order to guarantee urban water security. We draw from a decolonial reading of territory aligned to a Global South perspective and different from the Anglophone vision that understands territory as political-economic and politicalstrategic relations tied to the sovereignty of the modern state (Halvorsen, 2019). In our framing, territories are spaces of struggle and resistance in response to an imposed development model since the Colonial period (Escobar, 2008; Moreano et al., 2017). 
Such understanding recognizes that different territories overlap in place and time and meanings and cultural practices. Such multiple territories can lead to situations of conflict, especially when social movements occupy or remake spaces, reinventing their meaning and uses in a decolonial frame (Haesbaert, 2007; Porto-Gonçalves, 2009).

The understanding of urban water security dialogues with the concept of hydrosocial territories as the constitution of socio-environmental and spatially bounded multiscalar networks activated to guarantee access to water (Boelens et al., 2016; Hommes et al., 2018). In this understanding, water security strategies could mobilize distinct hydrosocial territories, with specific social actors, networks, rules, technologies, infrastructure and practices to access water. A relational approach to urban water security would subsequently recognize multiple hydro-social territories as the result of multiscalar and multidimensional flows of water and power beyond watersheds and consider rural/urban relations as part of the processes that constitutes such new territories (Empinotti et al., 2021; Carmo \& Anazawa, 2017; Pires do Rio, 2017; Hommes \& Boelens, 2017; Bernabeu \& Martín, 2019).

The construction of hydro-social territories through urban water security is influenced by processes such as labor relations and citizens' rights to the city, our second point of entrance. Shifting forms of labor in cities plays are critical to understanding water security. As communities are forced into increased informal and precarious work, the cost and time spent to maintain, improve, and contest access to water fluctuates depending on a dynamic labor market and its relation to insecure tenure rights. These structural dimensions are rendered fluid as legislative, institutional, and socio-political contexts are interpreted and reimagined by the state, non-state actors, and communities. For instance, literature on infrastructure has demonstrated how informal 
residents can gain legal recognition by demanding physical connections to their settlements (Holston, 2009). Yet, as Anand (2017) also reminds us, access to physical infrastructure does not guarantee permanent tenure or access rights, and, in reality, many communities experience cyclical episodes of securing or losing rights as urban political economies and governance regimes change.

If such struggles for water are spatialized through territories, labor relations and citizens' rights to the city; it also materializes through infrastructure, our third point of entrance. The economic importance of urban areas, combined with the growing demand for water by cities that often exceeds the resources within their boundaries, have been used to justify supply-led approaches oriented around infrastructure, especially with increased emphases on scarcity as the key issue (Crow-Miller et al., 2017). Securing water at the city level does not necessarily increase water security at the household level, however. Moreover, defining 'access' in practice needs care: even if low-income households have water connections, many experience intermittent supply, low water pressure, and inability to pay bills (Rodina, 2016). These conditions give rise to forms of heterogeneous off-grid infrastructures that are found in cities globally (Vandewalle \& Jepson, 2015; Deitz \& Meehan, 2019). To better understand the key relations that produce urban water security, it is necessary to think and plan beyond those who are connected to formal public services.

Furthermore, it is largely institutional arrangements and governance processes that determine access to (formal) infrastructure, which, as above, is often minimal for those living in low-income settlements. Such assumption leads to our fourth entrance point: water governance practices. The formation of institutional landscapes of water governance is a consequence of urbanization processes that encompasses water control and leads to particular political economic relations, which in turn determine by whom 
and how water is controlled, produced, and distributed in urban areas (Bakker \& Morinville, 2013). While some authors focus on the nature of governance for water security, emphasizing institutional modalities modalities and the principles of 'good governance' as the pathway towards water security, this can overlook how governance choices are shaped by power relations and politics (Bakker \& Morinville, 2013; Empinotti et al., 2019).

From a relational standpoint, the object of water governance is not water itself, but the relationship between water and people, in terms of who can access water and under what conditions. It is, thus, important to move beyond the format of decisionmaking frameworks and procedures for water and attend to the role of power relations in producing water governance arrangements that in turn shape water-society relations (Jepson et al., 2017). Such governance shifts in urban contexts include neoliberalization (e.g. privatization), rescaling (e.g. decentralization), and regulation (e.g. formalisation) of water provision, which have been promoted as pragmatic responses to improve water governance, but have often served the agendas of political power and capital accumulation more than the interests of urban water consumers (Empinotti et al., 2019). Therefore, a critical framework for urban water security should reveal the unequal power relations embedded in urban water governance structures and processes in order to define entry-points to contest these through political engagements and mobilizations.

Based on that, it is key that institutions and water governance practices involve the mobilization and participation of a diversity of social actors in co-producing solutions. The role of the state would be to guarantee water access to all, even under a water pricing system. How should be done? This question leads to our fifth entering point: social action. We understand that social action comes from civil society organizations, potentially balancing state and private sector agendas in the institutional 
practices of governance. Social participation is understood to be present not just in formal spaces of participation but also in neighborhood associations and other types of movements. In this sense, participatory processes go beyond negotiation practices and the finding of common agreements and instead include potentially innovative solutions to water access co-produced by different bodies of knowledge and praxis (Edelenbos et al., 2011). In this regard, co-production of knowledge can be seen as an opportunity to embed the creative and imaginative wisdom of diverse stakeholders into the processes of water security.

Directing attention towards social action and mobilization for water security enables us to capture how residents act collectively to obtain, manage, and maintain water (and other) services in a context of land, housing tenure, social, financial and environmental insecurity. In this sense, attention to social mobilization and action reflects the fact that "culturally-shared views of water fundamentally shape people's understanding and experiences of water security" (Jepson et al., 2017; Wantzen, 2016). Attention to knowledge co-production and social action could lead to the creation of more sustainable and socially informed infrastructures and practices that cultivate and are cultivated by lived experiences with water. Strengthening people's bonds to the elements of nature that provide ecosystemic and cultural services can improve the quality of life of vulnerable communities, society in general, and the biophysical environment.

\section{Conclusion}

Theorizing urban water security as a relational process contributes to a new water culture based on social engagement, co-production of knowledge, and attention to power and how it is materialized. Attention to urban water security asks us to focus on how we use water, who benefits from it, who is excluded, and how to these exclusions 
can be remedied. Social engagement and co-production are critical to achieving relational water security, which recognizes hydro-social relations that mediate the conditions of water's materiality within ecosystems, political equality, and human wellbeing. We suggest that attention to urban water security must go beyond the use of percentage rates to measure access to water and infrastructure. Infrastructure is important but is not the only indicator of success. Instead, monitoring infrastructure should be part of a broader approach that prioritizes the social relations that underpin water insecurity and goes beyond the urban as merely the context in which water provision and risk take place. We seek to mobilize this concept to envision meaningful water policies and hydro-social practices to enhance social equity and empowerment for urban communities. This is a shift from the sectorial and fragmented perspective towards a territorial approach. The understanding of a relational urban water security as the result of interrelations and intersections though the processes of urbanization could lead to equality and justice in water access, putting in practice the principal of water access as a right.

\section{References}

Aalbers, M. B., Rolnik, R., \& Krijnen, M. (2020). The Financialization of Housing in Capitalism's Peripheries. Housing Policy Debate, 30(4), 481-485. https://doi.org/10.1080/10511482.2020.1783812

Allan, J. V., Kenway, S. J., \& Head, B. W. (2018). Urban water security-What does it mean? Urban Water Journal, 15(9), 899-910. https://doi.org/10.1080/1573062X.2019.1574843 
Anand, N. (2017). Hydraulic City: Water and the Infrastructures of Citizenship in Mumbai (p. dup;9780822373599/1). Duke University Press. https://doi.org/10.1215/9780822373599

Bakker, K., \& Morinville, C. (2013). The governance dimensions of water security: A review. Philosophical Transactions of the Royal Society A: Mathematical, Physical and Engineering Sciences, 371(2002), 20130116. https://doi.org/10.1098/rsta.2013.0116

Beckner, S., Jepson, W., Brannstrom, C., \& Tracy, J. (2019). 'The San Antonio River Doesn't Start in San Antonio, It Now Starts in Burleson County': Stakeholder Perspectives on a Groundwater Transfer Project in Central Texas. Society \& Natural Resources, 32(11), 1222-1238. https://doi.org/10.1080/08941920.2019.1648709

Bernabeu, M.M., \&Martín, F. (2019). El periurbano recreado. Urbanizaciones cerradas como nuevos hídricos en el paisage hídrico del área Metropolitana de Mendonza, Argentina. Quid, 16(11), 55-85.

Birkenholtz, T. (2016). Dispossessing irrigators: Water grabbing, supply-side growth and farmer resistance in India. Geoforum, 69, 94-105. https://doi.org/10.1016/j.geoforum.2015.12.014

Bhan, G. (2019). Notes on a Southern urban practice. Environment and Urbanization, 31(2), 639-654.

Boelens, R., Hoogesteger, J., Swyngedouw, E., Vos, J., \& Wester, P. (2016). Hydrosocial territories: A political ecology perspective. Water International, 41(1), 1-14. https://doi.org/10.1080/02508060.2016.1134898

Brears, R. C. (2016). Urban water security. John Wiley \& Sons.

Brenner, N., \& Schmid, C. (2015). Towards a new epistemology of the urban?. City, 19(2-3), 151-182.

Budds, J. (2019). Geoforum, 98, 
Caldeira, T. P. (2017). Peripheral urbanization: Autoconstruction, transversal logics, and politics in cities of the global south. Environment and Planning D: Society and Space, 35(1), 3-20.

Cardone, R., \& Fonseca, C. (2006). Water Sector in Small Urban Centres: Analysis of donor flows to water supply and sanitation services (No. 2; UN-Habitat Report on the Water Sector in Small Urban Centres). UN-Habitat (United Nations Human Settlements Programme).

Carmo, R. L. do, \& Anazawa, T. M. (2017). Hidromegalópole São Paulo-Rio de Janeiro: Escassez hídrica, sobreposição de espacialidades e conflitos.

Clark, C. (2019). Race, austerity and water justice in the United States: Fighting for the human right to water in Detroit and Flint, Michigan. In Water politics: Governance, justice and the right to water (pp. 175-188). Routledge.

Cook, C., \& Bakker, K. (2012). Water security: Debating an emerging paradigm. Global environmental change, 22(1), 94-102.

Cronon, W. (2009). Nature's metropolis: Chicago and the Great West. WW Norton \& Company.

Crow-Miller, B., Webber, M., \& Molle, F. (2017). The (re) turn to infrastructure for water management?. Water Alternatives.

Deitz, S., \& Meehan, K. (2019). Plumbing Poverty: Mapping Hot Spots of Racial and Geographic Inequality in U.S. Household Water Insecurity. Annals of the American Association of Geographers, 109(4), 1092-1109. https://doi.org/10.1080/24694452.2018.1530587

Doshi, S. (2017). Embodied urban political ecology: Five propositions. Area, 49(1), 125-128. 
Edelenbos, J., Van Buuren, A., \& van Schie, N. (2011). Co-producing knowledge: joint knowledge production between experts, bureaucrats and stakeholders in Dutch water management projects. Environmental science \& policy, 14(6), 675-684.

Empinotti, V. L., Budds, J., \& Aversa, M. (2019). Governance and water security: The role of the water institutional framework in the 2013-15 water crisis in São Paulo, Brazil. Geoforum, 98, 46-54. https://doi.org/10.1016/j.geoforum.2018.09.022

Empinotti, V. L., Tadeu, N. D., Fragkou, M. C., \& Sinisgalli, P. A. (2021). Desafios da governança da água: A contribuição do conceito de territórios hidrossociais para novos arranjos intitucionais. Estudos Avançados.

Escobar, A. (2008). Territories of difference: Place, movements, life, redes. Duke University Press.

Fernández, M. M. B., \& García, F. M. (2019). El periurbano recreado. Urbanizaciones cerradas como nuevos híbridos en el paisaje hídrico del Área Metropolitana de Mendoza, Argentina. Quid 16. Revista del Área de Estudios Urbanos, O(11), 55-85.

Fernandez, R., \& Aalbers, M. B. (2020). Housing Financialization in the Global South: In Search of a Comparative Framework. Housing Policy Debate, 30(4), 680-701. https://doi.org/10.1080/10511482.2019.1681491

Ferrara, L. N. (2013). Urbanização da natureza: da autoprovisão de infraestruturas aos projetos

de recuperação ambiental nos mananciais do sul da metrópole paulistana. (Doctoral dissertation, University of São Paulo) doi:10.11606/T.16.2013.tde-25092013-110858.

Fields, D. (2017). Urban struggles with financialization. Geography Compass, 11(11), e12334. https://doi.org/10.1111/gec3.12334 
Furlong, K., \& Kooy, M. (2017). Worlding Water Supply: Thinking Beyond the Network in Jakarta. International Journal of Urban and Regional Research, 41(6), 888-903. https://doi.org/10.1111/1468-2427.12582

Gimelli, F. M., Bos, J. J., \& Rogers, B. C. (2018). Fostering equity and wellbeing through water: A reinterpretation of the goal of securing access. World Development, 104(C), 19.

Grey, D., \& Sadoff, C. (2005). Water resources, growth and development. Prepared for the Panel of Finance Ministers, the UN Commission for Sustainable Development.

Haesbaert, R. (2007). Território e multiterritorialidade: Um debate. GEOgraphia, 9(17), Article 17. https://doi.org/10.22409/GEOgraphia2007.v9i17.a13531

Halvorsen, S. (2019). Decolonising territory: Dialogues with Latin American knowledges and grassroots strategies. Progress in Human Geography, 43(5), 790-814. https://doi.org/10.1177/0309132518777623

Harvey, D. (2007). A brief history of neoliberalism. Oxford University Press, USA.

Heynen, N., Kaika, M., \& Swyngedouw, E. (Eds.). (2006). In the nature of cities: urban political ecology and the politics of urban metabolism. Taylor \& Francis.

Hoekstra, A. Y., Buurman, J., \& Ginkel, K. C. H. van. (2018). Urban water security: A review. Environmental Research Letters, 13(5), 053002. https://doi.org/10.1088/1748$\underline{9326 / \mathrm{aaba52}}$

Hommes, L., Boelens, R., Harris, L. M., \& Veldwisch, G. J. (2019). Rural-urban water struggles: Urbanizing hydrosocial territories and evolving connections, discourses and identities. Water International, 44(2), 81-94.

https://doi.org/10.1080/02508060.2019.1583311 
Hommes, L. M., Boelens, R. A., Abadia, B. D., Hidalgo, J. P., \& Dijk, J. D. H. van. (2018).

Reconfiguration of Hydrosocial Territories and Struggles for Water Justice: From Part II - Hydrosocial De-Patterning and Re-Composition. Water Justice, 151-168.

Hommes, L., \& Boelens, R. (2017). Urbanizing rural waters: Rural-urban water transfers and the reconfiguration of hydrosocial territories in Lima. Political Geography, 57, 71-80. https://doi.org/10.1017/9781316831847.010

Holston, J. (2009). Insurgent citizenship: Disjunctions of democracy and modernity in Brazil. Princeton university press.

Islar, M. (2012). Privatised hydropower development in Turkey: A case of water grabbing? Water Alternatives, 5(2), 376-391.

Jaramillo, P., \& Nazemi, A. (2018). Assessing urban water security under changing climate: Challenges and ways forward. Sustainable Cities and Society, 41, 907-918. https://doi.org/10.1016/j.scs.2017.04.005

Jensen, O., \& Wu, H. (2018). Urban water security indicators: Development and pilot. Environmental Science \& Policy, 83, 33-45. https://doi.org/10.1016/j.envsci.2018.02.003

Jepson, W., \& Vandewalle, E. (2016). Household Water Insecurity in the Global North: A Study of Rural and Periurban Settlements on the Texas-Mexico Border. The Professional Geographer, 68(1), 66-81. https://doi.org/10.1080/00330124.2015.1028324

Jepson, W., Budds, J., Eichelberger, L., Harris, L., Norman, E., O'Reilly, K., Pearson, a.; Shah, J., Shinn, J., Staddon, C., Stoler, J., Wutich, A. \& Young, S. (2017). Advancing human capabilities for water security: A relational approach. Water Security, 1, 46-52. Jepson, W., Wutich, A., \& Harris, L. M. (2019). Water-security capabilities and the human right to water. Water Politics: Governance, Justice and the Right to Water, 84. 
Jorge, S. (2020). The Financialization of the Margins of Maputo, Mozambique. Housing Policy Debate, 30(4), 606-622.

Kooy, M. (2014). Developing Informality: The Production of Jakarta's Urban Waterscape. Water Alternatives, 7, 35-53.

Kowarick, L. (1979). A espoliação urbana (Vol. 44). Editora Paz e Terra.

Loftus, A. (2015). Water (in) security: Securing the right to water. The Geographical Journal, 181(4), 350-356.

Maricato, E. (1979). A produção capitalista da casa (e da cidade) no Brasil industrial (Vol. 1). Editora Alfa-Omega.

McDonald, R. I., Douglas, I., Revenga, C., Hale, R., Grimm, N., Grönwall, J., \& Fekete, B. (2011). Global urban growth and the geography of water availability, quality, and delivery. Ambio, 40(5), 437-446. https://doi.org/10.1007/s13280-011-0152-6

McDonald, R. I., Weber, K., Padowski, J., Flörke, M., Schneider, C., Green, P. A., Gleeson, T., Eckman, S., Lehner, B., Balk, D., Boucher, T., Grill, G., \& Montgomery, M. (2014). Water on an urban planet: Urbanization and the reach of urban water infrastructure. Global Environmental Change, 27, 96-105. https://doi.org/10.1016/j.gloenvcha.2014.04.022

Mehta, L. (2014). Water and Human Development. https://doi.org/10.1016/j.worlddev.2013.12.018

Morckel, V. (2017). Why the Flint, Michigan, USA water crisis is an urban planning failure. Cities, 62, 23-27. https://doi.org/10.1016/j.cities.2016.12.002

Moreano, M., Francisco, M., \& Bryant, R. (2017). Hacia una ecología política global: Aportes desde el sur. Ecología Política Latinoamericana. Pensamiento Crítico, Diferencia Latinoamericana y Rearticulación Epistémica, 1, 197-212. 
Nazemi, A., \& Madani, K. (2017). Urban water security: Emerging discussion and remaining challenges. https://doi.org/10.1016/J.SCS.2017.09.011

Octavianti, T. (2019). De-and Re-politicisation of Water Security as Examined Through the Lens of the Hydrosocial Cycle: The Case of Jakarta's Sea Wall Plan. Water Alternatives, 12(3).

Padowski, J. C., Carrera, L., \& Jawitz, J. W. (2016). Overcoming Urban Water Insecurity with Infrastructure and Institutions. Water Resources Management: An International Journal, Published for the European Water Resources Association (EWRA), 30(13), $4913-4926$.

Pires do Rio, G. (2017). ÁGUA: URGÊNCIA DE UMA AGENDA TERRITORIAL. Ambiente \& Sociedade, XIX, 105.

Porto-Gonçalves, C. W. (2009). De Saberes y de Territorios-Diversidad y emancipación a partir de la experiencia latino-americana. Polis. Revista Latinoamericana, 22, Article 22. http://journals.openedition.org/polis/2636

Ranganathan, M. (2014). Paying for Pipes, Claiming Citizenship: Political Agency and Water Reforms at the Urban Periphery. International Journal of Urban and Regional Research, 38(2), 590-608. https://doi.org/10.1111/1468-2427.12028

Richter, B. D., Abell, D., Bacha, E., Brauman, K., Calos, S., Cohn, A., Disla, C., O’Brien, S. F., Hodges, D., Kaiser, S., Loughran, M., Mestre, C., Reardon, M., \& Siegfried, E. (2013). Tapped out: How can cities secure their water future? Water Policy, 15(3), 335363. https://doi.org/10.2166/wp.2013.105

Rodina, L. (2016). Human right to water in Khayelitsha, South Africa-Lessons from a 'lived experiences' perspective. Geoforum, 72(2016), 58-66.

Scott, C. A., Meza, F. J., Varady, R. G., Tiessen, H., McEvoy, J., Garfin, G. M., Wilder, M., Farfán, L. M., Pablos, N. P., \& Montaña, E. (2013). Water Security and Adaptive 
Management in the Arid Americas. Annals of the Association of American

Geographers, 103(2), 280-289. https://doi.org/10.1080/00045608.2013.754660

Seabra, O. C. de L. (2018). Bacia do Alto Tietê: A montagem do sistema hidrelétrico de São Paulo e sua problemática. Boletim Paulista de Geografia, O(100), 56-84.

Sultana, F. (2011). Suffering for water, suffering from water: Emotional geographies of resource access, control and conflict. Geoforum, 42(2), 163-172. https://doi.org/10.1016/j.geoforum.2010.12.002

Tomaz, P., Jepson, W., \& Santos, J. de O. (2020). Urban Household Water Insecurity from the Margins: Perspectives from Northeast Brazil. The Professional Geographer, 72(4), 481-498.

Truelove, Y. (2019). Rethinking water insecurity, inequality and infrastructure through an embodied urban political ecology. WIREs Water, 6(3), e1342. https://doi.org/10.1002/wat2.1342

United Nations. (2013). Water Security \& the Global Water Agenda. Ontario, UNUINEWH, 47.

Vandewalle, E., \& Jepson, W. (2015). Mediating water governance: Point-of-use water filtration devices for low-income communities along the US-Mexico border. Geo: Geography and Environment, 2(2), 107-121. https://doi.org/10.1002/geo2.9

Wahby, N. (2019). The role of the state in urban development: the case of urban waterscapes in Cairo, Egypt (Doctoral dissertation, University of Cambridge).

Wantzen, K.M., Ballouche, A., Longuet, I., Bao, I., Bocoun, H., Cissé, L., Chauhan, M., Girard, P., Gopal, B., Kane, A., Marchese, M.R., Nautiyal, P. Teixeira, P. \& Zalewski, M. (2016). River Culture: an eco-social approach to mitigate the biological and cultural diversity crisis in riverscapes. Ecohydrology \& Hydrobiology, 16(1), 7-18. https://doi.org/10.1016/j.ecohyd.2015.12.003 
Weber, R. (2010). Selling City Futures: The Financialization of Urban Redevelopment Policy. Economic Geography, 86(3), 251-274. https://doi.org/10.1111/j.1944$\underline{8287.2010 .01077 . \mathrm{x}}$

Zeitoun, M., Lankford, B., Krueger, T., Forsyth, T., Carter, R., Hoekstra, A. Y., Taylor, R., Varis, O., Cleaver, F., Boelens, R., Swatuk, L., Tickner, D., Scott, C. A., Mirumachi, N., \& Matthews, N. (2016). Reductionist and integrative research approaches to complex water security policy challenges. Global Environmental Change, 39, 143-154. https://doi.org/10.1016/j.gloenvcha.2016.04.010 